\title{
Analysis of Structure, Mechanism of Action and Efficacy of Potential and Ideal COVID-19 Treatments
}

\author{
Halim $\mathrm{M}^{1^{*}}$, Halim $\mathrm{A}^{2}$, Trivosa $\mathrm{V}^{3}$ \\ ${ }^{1}$ University of Salford, MSc Biomedical Science, Greater Manchester, United Kingdom \\ ${ }^{2}$ Zhong Shan Hospital, Shanghai Medical College, Fudan University, Shanghai, China \\ ${ }^{3}$ Hospital of Stomatology, Wuhan University, Wuhan, China
}

Corresponding Author: Michael Halim

Address: University of Salford, MSc Biomedical Science, Greater Manchester, United Kingdom.

Received date: 24 September 2020; Accepted date: 13 November 2020; Published date: 21 November 2020

Citation: Halim M, Halim A, Trivosa V. Analysis of Structure, Mechanism of Action and Efficacy of Potential and Ideal COVID-19 Treatments. J Health Care and Research. 2020 Nov 21;1(3):197-208.

Copyright (C) 2020 Halim M, Halim A, Trivosa V. This is an open-access article distributed under the Creative Commons Attribution License, which permits unrestricted use, distribution, and reproduction in any medium, provided the original work is properly cited.

\begin{abstract}
Introduction: Covid-19 has a positive-stranded RNA, which is characterised by protruding spikes that enhance replication.

Objective: To offer detailed information on treatment approaches that are applied in preventing Covid-19.

Methods: Information was obtained from PubMed and CINAHL. SPSS and Microsoft Excel were used to analyse the data and graph it accordingly.

Results: There are many treatments such as chloroquine and hydroxychloroquine, RDV, Lopinavir or Ritonavir, and Arbidol combined with Favipiravir. On analysing the structures and mechanisms, RDV indicated better secondary and primary outcomes, including early clearance of the viral load and reduced hospital stay. Chloroquine and hydroxychloroquine were found to be efficacious in vitro; however, their effectiveness in vitro declined due to adverse outcomes.

Conclusion: Due to the repurposing of the drugs described, it is important to combine treatments to control Covid-19 while developing vaccines. There is a need for further extensive research on huge samples to establish the efficiency of specific therapies and treatments.
\end{abstract}

\section{Keywords}

Lopinavir, COVID-19, Ritonavir, SARS-CoV-2, Chloroquine, Remdesivir, Favipiravir, Arbidol, hydroxychloroquine

\section{Background}

The world is experiencing a distressing pandemic of the novel Coronavirus disease, commonly referred to as Covid-19 [1]. Covid-19 is caused by Severe Acute Respiratory Syndrome Coronavirus-2 (SARS-CoV-2), which affects the lungs. The coronaviruses enter the human cells by attaching their spike-like surfaces to the angiotensin-converting enzyme-2 (ACE-2) [1].
Covid-19 can be traced back to Wuhan City in China, where novel cases of human pneumonia were recognised on December 1, 2019 [2]. The symptomatology seen in the patients included malaise, fever, dyspnoea, and dry cough [2]. SARS-CoV-2 is characterised by a positive-stranded RNA [2] that has an oval or round particles with a diameter of $140 \mathrm{~nm}$. In addition, SARS-CoV-2 is categorised among 
coronaviruses, which fall under the beta-class and among is ranked among the various sub-types that are linked to high morbidity and mortality rates [3].

There are four operational genes associated with SARS-CoV-2, including nucleocapsid $(\mathrm{N})$, membrane glycoprotein $(\mathrm{M})$, spike protein $(\mathrm{S})$, and Small Membrane Protein (SM). The ORF1 and the ORF1a are the sections, which are responsible for encoding nonstructural protections. The S Protein gene develops a receptor biding locale on the virus' surface while the $\mathrm{M}$ protein develops the virions to trigger different shapes. The different shapes foster orientation and curvature of the membranes and transport nutrients into the membrane. The protein is considered fundamental when collecting and discharging the virus as well as helping its pathogenesis. Further, $\mathrm{N}$ proteins are essential when attaching the virus and the RNA genomes and for viral strength [4]. The viral sequence of SAR-CoV-2 depicts a similarity of $96 \%$, which is likened to coronavirus in bats [5]. The figure below (Fig-1) shows the structure of SAR-CoV-2.

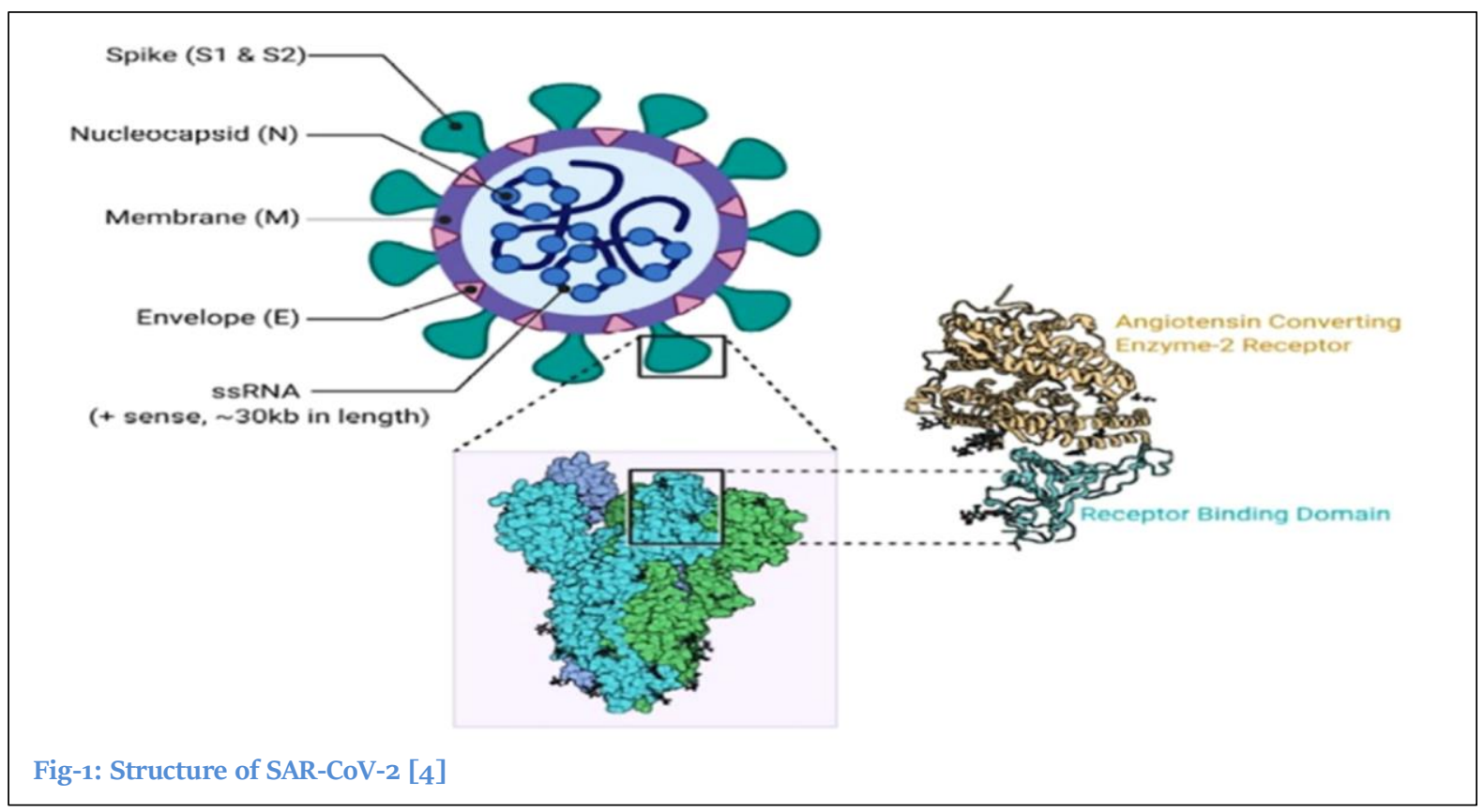

The virus encrypts protein $S$, which has the binding receptors whose contact $\mathrm{ACE} 2$ fosters fusion of various membranes and allows the uptake via endocytosis into the victim's lungs. The S protein is important when recognising and binding the virus onto the human host for mediation purposes and fusion into the membranes of the cell. The immunologic composition of $\mathrm{S}$ protein is similar to SARS-CoV and SAR-CoV-2 [6]. After entering the human cell, $\mathrm{S}$ proteins start to assemble and synthesise the important proteins to foster replication. In addition, $\mathrm{S}$ glycoprotein attaches on the ACE-2 and enters the targeted cells in the endosomal path. After it enters the cell, ORF1a and ORF1b genes reproduce polyprotein through the viral replication mechanisms. The polyproteins are significant in the replication of viral genes [7].

\section{Methods}

\section{Database Search:}

The researcher conducted a search on various databases such as PubMed Central and obtained grey literature from CINAHL. The other publishers from which more details were obtained included PLOS One, Peer J, and Elsevier. Keywords were utilised in the search criteria to widen and narrow the search and obtain relevant articles for analysis. In particular, the Boolean operators were applied to ensure that the search undertaken retrieves articles with appropriate details. The keywords used were "Covid-19" OR "SARCov-2" AND "Treatment."

\section{Screening of the Articles:}

At the screening phase, the researcher read through the abstracts to establish whether they address the topic under study. Further, the researcher checked if 
the titles of the articles retrieved had the key study words. In line with the inclusion criteria, the investigator was keen to ensure that the articles obtained were randomised control trials.

\section{Exclusion and Inclusion Criteria:}

Given that the novel coronavirus disease was discovered recently, the articles included in the study ought to be within that timeframe. In particular, this study included studies published in 2019 and 2020. Further, studies that encompassed important and relevant information were the only ones analysed. To have high quality-level analysis, the researcher chose to include randomised trials only. Articles that applied cross-sectional study designs and those that were ranked in the low levels were exempted from the research.

\section{Graphing Software:}

The researcher applied both SPSS and Microsoft Excel to analyse and provide a graphic presentation of the information obtained from the study articles. Microsoft Excel was important in translating the data from the tables, whereas SPSS was applied in analysing the information using the relevant statistical techniques such as regression and correlation.

\section{Results}

Remdesivir (RDV):

$\mathrm{RDV}$ is a phosphoramidite prodrug, which substitutes the nucleotide analogues [8]. It is an RdRp inhibitor for coronavirus replication [9] in the epithelial cells contests with ATP molecules by deferring chain termination. Once in the cell membrane, metabolism takes place and produces nucleoside monophosphate with the initiation of hydrolysis of the body's amino acids to produce carboxylate groups that form phenoxide. Cyclic anhydride breaks down with the help of water to form nucleoside monophosphate, which yields active nucleoside triphosphates that are used by RdRp [10]. RDV plays significant roles both in and outside the non-segmented RNA viruses; for instance, in the Ebola virus [11], Nipah virus [12], and respirational syncytial virus [13]. The efficaciousness of RDV has been seen in ex vivo and animal models with regards to both MERSCov and SARS-Cov $[14,15]$.

In line with the efficacy or RDV, people that use the drug clinically improve faster in less than 10 days. However, $66 \%$ of RDV and $64 \%$ placebo recipients had adversarial outcomes. $12 \%$ of individuals administered with RDV and $5 \%$ of those in the placebo were prematurely withdrawn because of the adverse outcomes [16]. RDV decreases the viral load and quantitative PCR, eliminating the virus within about 28 days, as shown in Fig-2 [17].

Table-1 is a comparison of clinical outcomes when patients are given RDV against the individuals in a

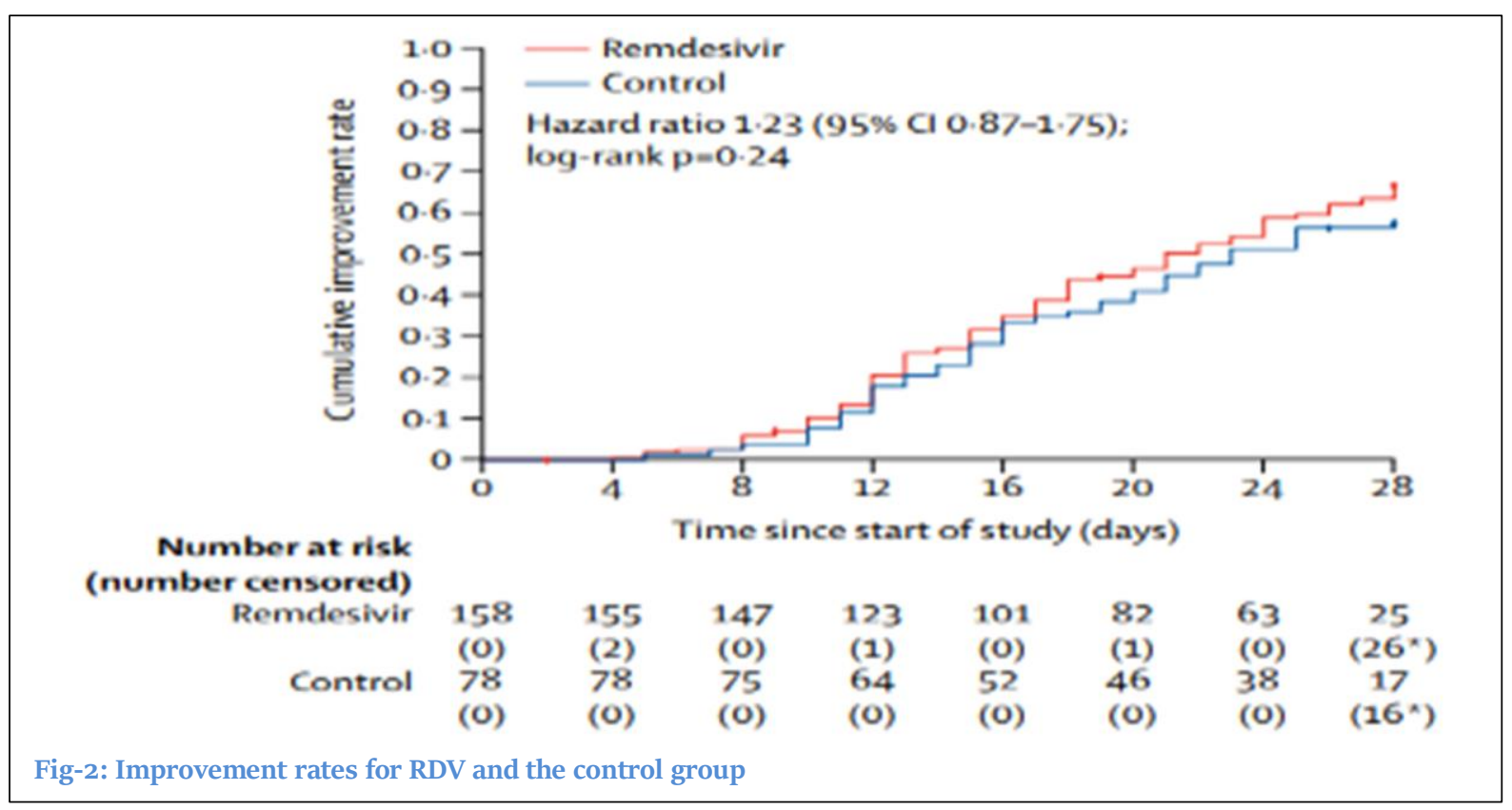




\begin{tabular}{|c|c|c|c|c|c|c|c|c|}
\hline \multicolumn{9}{|c|}{ Table-1: Using hydroxychloroquine to control SARS-CoV-2 [21] } \\
\hline Variables & $\begin{array}{c}\approx \text { of patients that } \\
\text { tested negative } \\
\text { after } 72 \text { hours }\end{array}$ & P-value & $\begin{array}{l}=\text { of patients that } \\
\text { tested negative } \\
\text { after } 96 \text { hours }\end{array}$ & P-value & $\begin{array}{l}\approx \text { of patients that } \\
\text { tested negative } \\
\text { after } 120 \text { hours }\end{array}$ & P-value & $\begin{array}{l}\text { = of patients that } \\
\text { tested negative } \\
\text { after } 144 \text { hours }\end{array}$ & P-value \\
\hline $\begin{array}{l}\text { Patients treated } \\
\text { with } \\
\text { hydroxychloroquine }\end{array}$ & 10 out of 20 or $50 \%$ & 0.05 & 12 out of 20 or $60 \%$ & 0.04 & 13 out of 20 or $65 \%$ & 0.006 & 14 out of 20 or $70 \%$ & 0.01 \\
\hline $\begin{array}{l}\text { Patients in the } \\
\text { control group }\end{array}$ & 1 out of 16 or $6.3 \%$ & & 4 out of 16 or $25 \%$ & & 3 out of 16 or $18.8 \%$ & & $\begin{array}{c}2 \text { out of } 16 \text { or } \\
12.5 \%\end{array}$ & \\
\hline
\end{tabular}

placebo. The techniques applied in the placebo in 4 weeks show a death rate $(3 \%)$ that is similar to those methods applied to RDV patients. Patients that were given RDV had significant clinical improvements when compared to the individuals in the placebo. There were notable advantages of using RDV; for example, the time on ventilators decreased, length of stay at the hospital declined, the length of patients on oxygen support decreased, and time to discharge also shortened.

There was a substantial improvement (68\%) among the patients that were administered with RDV. The improvements were noticed on the $18^{\text {th }}$ day among the individuals that were on oxygen support. $15 \%$ of the patients showed adverse conditions. 12 patients who were supplied with ambient air and low flow of supplemental oxygen showed improvement. 5 out of 7 patients were on non-invasive oxygen support.

\section{Hydroxychloroquine and Chloroquine:}

Chloroquine and hydroxychloroquine have an analogous structure with the potential to treat and cure malaria infections [18]. These two drugs have fragile bases that are broken to foster movement in and out of the cells. The parts of the drugs that are not broken down are then stored in the body at low $\mathrm{pH}$ [19]. Chloroquine hinders fusion of viral to cells by influencing ACE2 glycosylation.

Chloroquine was introduced to ex-vivo experimentation with Vera E6 cells an hour before attachment of the virus and after infection for a period of two hours. Real-time PCR showed that chloroquine impacts both pre- and post-entry viral activities. Hydroxychloroquine was found to be more efficacious than chloroquine in the provision of half-maximal responses [20]. Another study used SARS-CoV-2treated Vera E6 cells to evaluate the effectiveness of hydroxychloroquine and RDV at the start and after two hours alongside SAR-CoV-2 in the same way as RDV. Those administered with hydroxychloroquine indicated negative PCR results from nasopharyngeal samples obtained from treated and control individuals at 3-5 days and 6 days after inclusion. After 6 days, the results indicated that $70 \%$ of hydroxychloroquine was efficient in treating patients as opposed to the control group. This is illustrated in Table-1.

Azithromycin and chloroquine showed negative PCR outcomes and were significantly different between these categories of patients from day 3 through day 6 . On the last day (day 6), all patients who were administered with hydroxychloroquine and azithromycin were healed. For instance, 57.1 of these individuals showed positive outcomes when administered with hydroxychloroquine, while only $12.5 \%$ of the total patients in the control group were healed. The outcomes were statistically substantial. In addition, after the elapse of 6 days, individuals that were given chloroquine gave less positive PCR outcomes compared to those in a control category. Besides, patients who received hydroxychloroquine showed the highest decrease in positive cases compared to individuals from the control group at $7 \%$ and $20 \%$ correspondingly. Fig-3 clearly shows the number of patients whose PCR samples were positive through the 6 days.

\section{Lopinavir/Ritonavir:}

The protease enzymes are regarded as antecedents for viral protein development and are vital for the viral 
lifecycle [22]. This drug is a strong inhibitor of protease-related activities used in the management of HI-1 [23]. Ritonavir inhibits cytochrome p45o that forms and synthesises different molecules. The combination of lopinavir and ritonavir produces antiviral effects, which prevent the establishment of contagious virions. Lopinavir contains a peptidomimetic structure, which has a hydroxyethylene scaffold that mimicks peptide linkages; hence, useful in targeting HIV-1 protease enzymes [24].
Lopinavir and Ritonavir combination yielded high clinical improvement when compared to the control group (Fig-4). The combination of lopinavir-ritonavir and the control group indicated low viral loads, which cleared in 3 weeks [25]. When comparing arbidol and lopinavir-ritonavir by applying an antiviral agent, it was revealed that arbidol is connected to negligible RNA tests than Lopinavir-ritonavir [26]. The outcomes were shown to be statistically significant, as indicated in Fig-4.
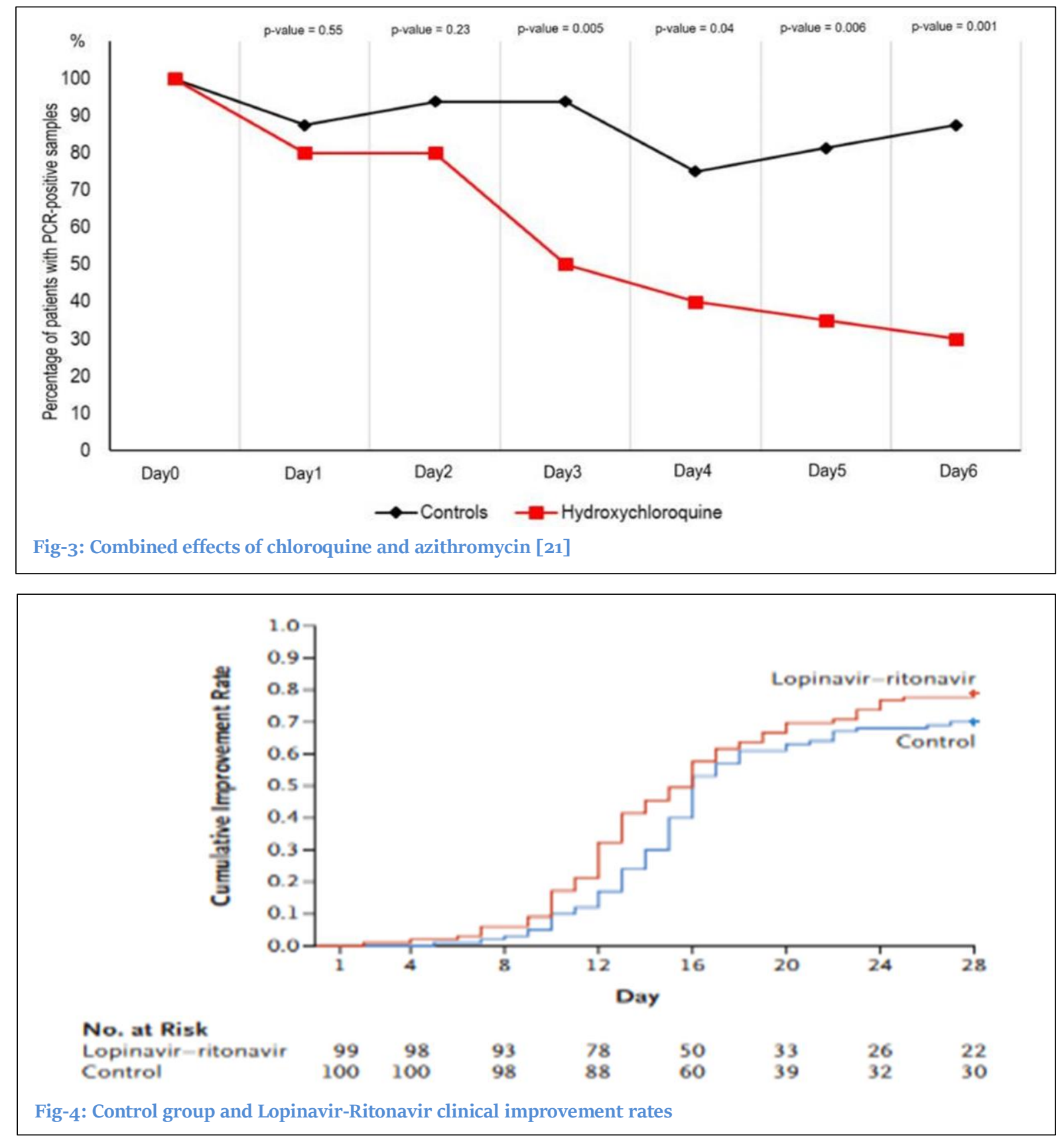
Patients that were treated with Lopinavir-Ritonavir did not show varied clinical improvements rates like the control group. Both groups had a median period of
6 days. There was little improvement even after applying the NEWS2 score tool, as indicated in Table-2.

\begin{tabular}{|c|c|c|}
\hline \multicolumn{3}{|c|}{ Table-2: Lopinavir-Ritonavir primary outcomes $[27]$} \\
\hline Characteristics & Lopinavir-Ritonavir & Standard Care \\
\hline NEWS2 Score at day 1 & 5.0 & 5.0 \\
\hline Hospitalization without supplemental oxygen & $11.10 \%$ & $17 \%$ \\
\hline Hospitalization requiring supplemental oxygen & $72.70 \%$ & $67 \%$ \\
\hline $\begin{array}{l}\text { Hospitalization requiring non-invasive mechanical } \\
\text { ventilation }\end{array}$ & $15.20 \%$ & $16 \%$ \\
\hline $\begin{array}{l}\text { Earlier symptoms (Less than 12days) } \\
\text { Later symptoms }\end{array}$ & $\begin{array}{l}42.40 \% \\
57.60 \%\end{array}$ & $\begin{array}{l}48 \% \\
52 \%\end{array}$ \\
\hline
\end{tabular}

Analysis of these outcomes showed low death rates $(19.2 \%)$ for the lopinavir-ritonavir combination compared to the findings from a standard method with $25 \%$. The individuals that were administered with lopinavir-ritonavir spent 12 days in the ICU with 14 days to discharge. Lopinavir-ritonavir had more patients (30\%) that showed clinical improvements during the second week. The individuals that were in the placebo had $45.5 \%$ of clinical outcomes (Table-3).

\begin{tabular}{|l|c|c|}
\hline \multicolumn{3}{|c|}{ Table-3: Secondary outcomes for Lopinavir-Ritonavir and standard care } \\
\hline \multicolumn{1}{|c|}{ Features } & Lopinavir-Ritonavir & Std Care \\
\hline Mortality at day 28 & $19.20 \%$ & $25 \%$ \\
\hline Clinical improvement & $6.10 \%$ & $2 \%$ \\
1 week & $45.50 \%$ & $30 \%$ \\
2 weeks & $78.80 \%$ & $70 \%$ \\
4 weeks & 2 to 11 & 7 to 17 \\
\hline & 8 to 17 & 7 to 17 \\
Length of stay at the ICU (days) & 4 to 14 & 3 to 9 \\
Survivors & 12 to 13 days \\
Non-survivors & \multicolumn{2}{|c|}{13 to 18 days } \\
\hline Hospital stay
\end{tabular}

\section{Umifenovir:}

Umifenovir is a derivative of indole carboxylic acid that prevents and cures influenza A and B and other arboviruses [28,29]. It is efficacious for viral strains, including human herpesvirus and Tacaribe arenavirus [30], Ebola [31], and Hepatitis [32]. Umifenovir has the potential of blocking the fusion of the viral-cell membrane and viral endosome by disrupting incorporation into the membrane. This is achieved by distracting the hydrogen bonds occurring in the phospholipid bilayer.
Umifenovir takes 9.1 days to show negative results, whereas lopinavir had 9 days. The drug had statistically significant results with low conversion rates when compared to the control group and Lopinavir. Besides, chest improvement and cough alleviation were significant at 1 and 2 weeks, respectively. PCR revealed that, in 21 days, there were no substantial changes between the times taken to decrease the viral loads as seen in Fig-5.

Combining Umifenovir with other drugs showed a favourable response. Chest $\mathrm{CT}$ had significant improvement when combined therapy was used. 
Besides, there were reduced positive cases than when applying monotherapy. Using control and Umifenovir was ineffective to treat Covid-19. For instance, the CT scores before admission and treatment until the initial negative tests were low than in the control group
(Table-4). After admission and treatment to the initial positive case, the CT scores were statistically substantial. Nonetheless, the test outcomes for the beginning of symptoms and time of stay were statistically insignificant.

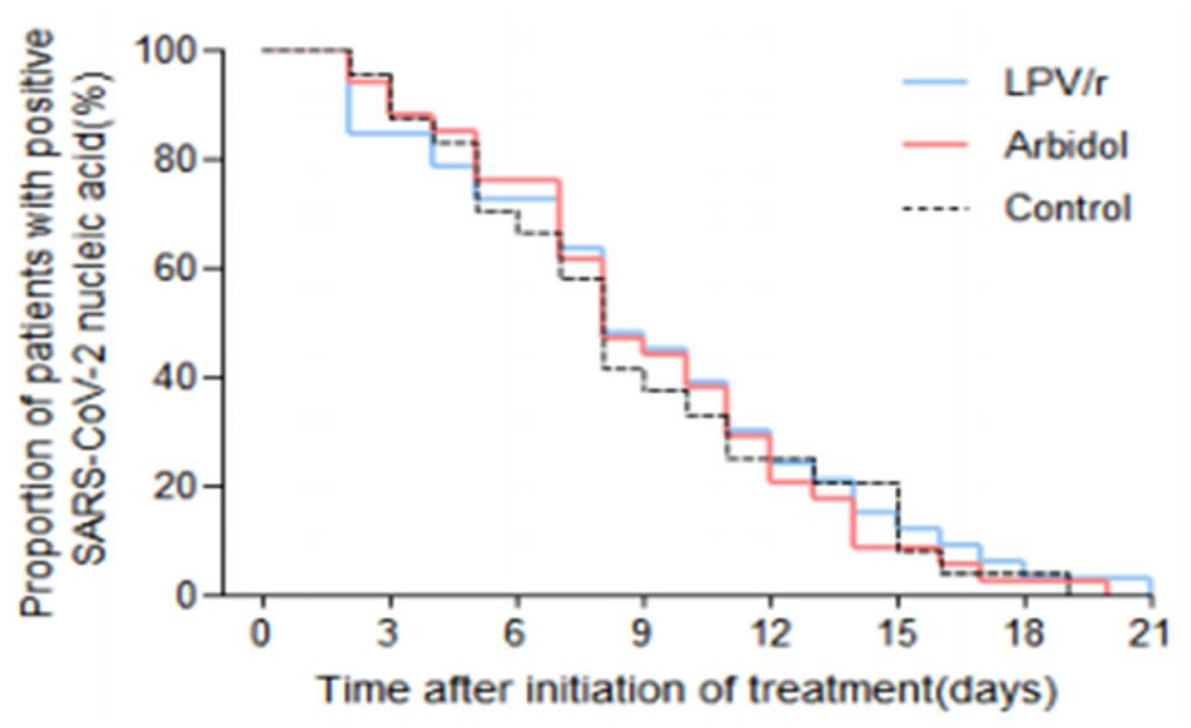

Fig-5: Changes seen in viral load clearance after treatment [33]

\begin{tabular}{|l|c|c|c|}
\hline \multicolumn{4}{|c|}{ Table-4: Comparing treatment in the control group and Umifenovir [34] } \\
\hline Characteristic & Umifenovir & Control & Statistical Significance \\
\hline CT score after treatment & 7 & 5 & 0.01 \\
\hline Time from admission to first negative test & 6 days & 3 days & 0.01 \\
\hline Time from onset of symptoms to first negative test & 18 days & 16 days & 0.42 \\
\hline Length of stay in hospital & 13 days & 11 days & 0.04 \\
\hline
\end{tabular}

\section{Favipiravir:}

Favipiravir trisphosphate has reference to as a purine nucleoside analogue, which inhibits RdRp activity [35]. The drug is active when used for influenza A, B, and in virus strains that are resistant to oseltamivir and zanamivir [36].

Favipiravir had 4 days as the average time needed to eradicate the viral load in comparison to the control group, which had 11 days. There was a statistically substantial relationship, as indicated in Fig-6.

Fig-7 illustrated the recovery rate from clinical treatment, which was high in Favipiravir than Arbidol.
There were substantial improvements observed between chest changes in light of treatments with Favipiravir in comparison with control groups as the time decreased. Irrespective of the particular changes noted, there were several adverse events linked to Favipiravir usage. For example, kidney and liver injury and diarrhoea were noted in the experimentation group, whereas twenty-five adverse reactions were evident in the control group.

\section{Summary}

With regard to the information provided, there is a number of drugs effective for the treatment and management of SAR-CoV-2 while some have reduced 


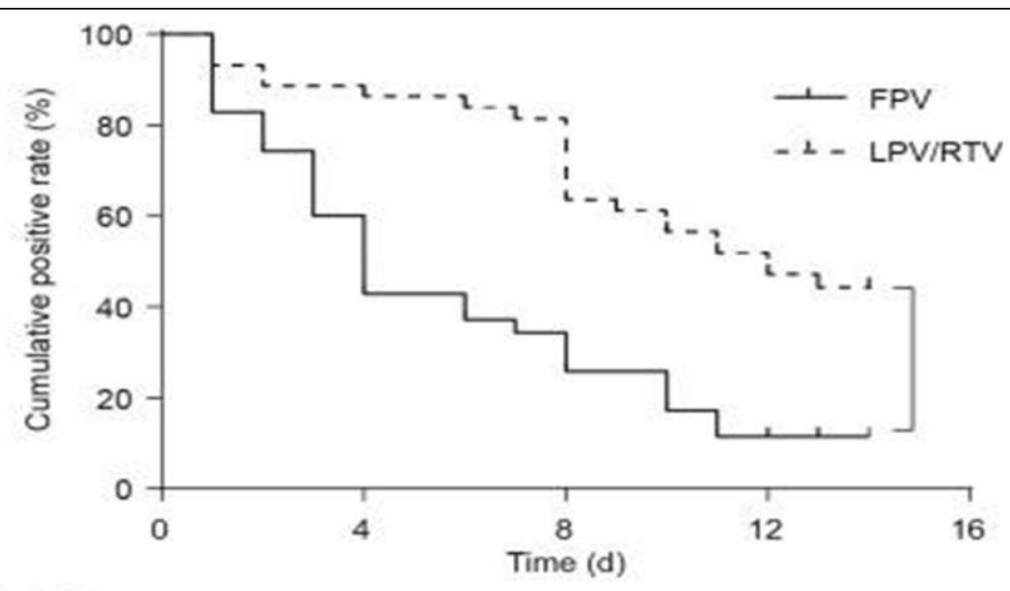

No. of patients

at risk

$\begin{array}{lrrrrr}\text { FPV } & 35 & 15 & 9 & 4 & 2 \\ \text { LPV/RTV } & 45 & 38 & 28 & 20 & 12\end{array}$

Fig-6: Treatment using Favipiravir had a positive decrease in the rate compared to ritonavir and lopinavir treatment [37].

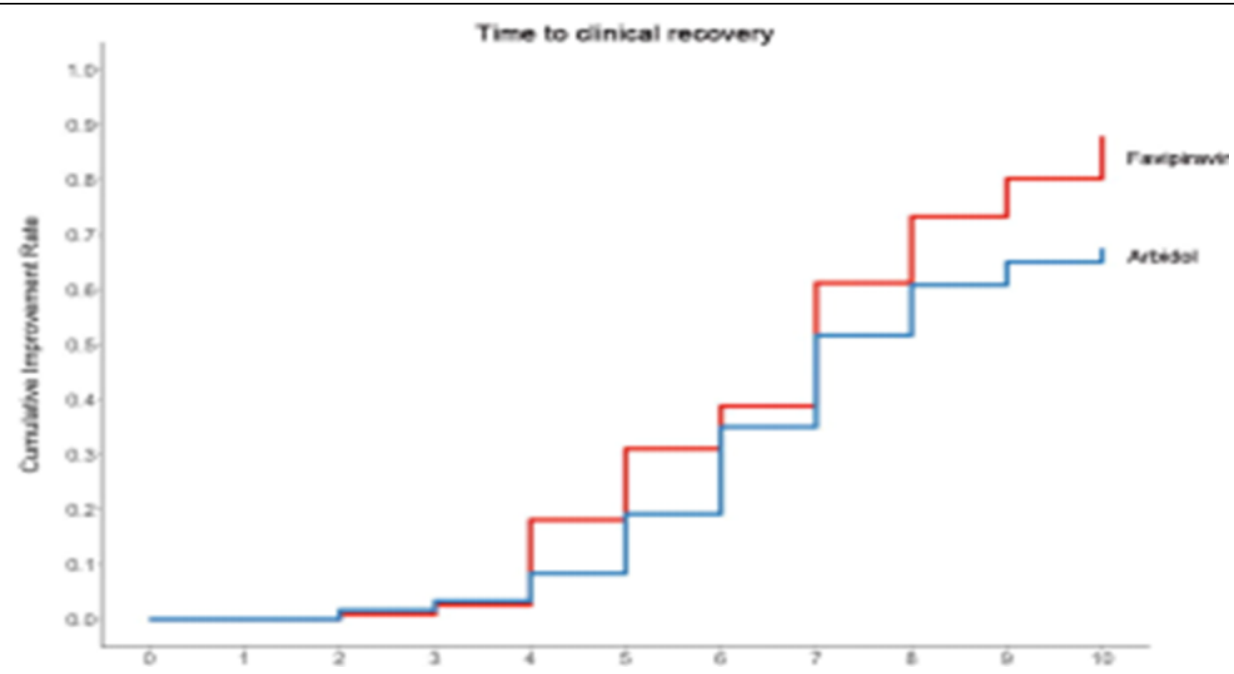

Fig-7: Clinical recovery rates compared between Arbidol and Favipiravir [37]

efficaciousness. Hydroxychloroquine efficiency has been demonstrated in vitro experimentations. Nonetheless, the use of hydroxychloroquine attenuates various side effects, particularly among patients that reported cardiovascular problems; hence, using it in managing SAR-CoV-2 is considerably limited. Combining Ritonavir and Lopinavir is useful; however, the combination has limited benefits just like Umifenovir. In perspective, there are limited drugs to control SARS-CoV-2 because of the nature of this unique illness and inadequate studies. The drugs described are repurposed from managing viral diseases and used directly to manage SARS-CoV-2.

\section{Meta-Analysis}

Mortality Rates and Adverse Scenarios (Table-5).

\section{Conclusion and Recommendations}

RDV was found to be the most efficacious treatment when managing Covid-19. Nonetheless, it is important to undertake further research, particularly on implementing combined therapies since such combinations showed significant improvements when yielding clinical outcomes. Combined therapy could be focused on drugs that use various phases of viral entry and duplication within the cells. Measures for combined therapies require evaluations for the outcomes provided. In addition to the application of 
combined therapies, there is a need for further emphasis on medicine repurposing. Majority of the drugs described have been utilised in the treatment and management of various conditions, including novel Covid-19.

\begin{tabular}{|c|c|c|}
\hline \multicolumn{3}{|c|}{ Table-5: Rate of mortality and adverse events } \\
\hline Treatment & Mortality Rates & Adverse events \\
\hline \multirow{2}{*}{ Treatment with Remdesivir } & \multirow{2}{*}{$13 \%(n=53)$} & $60 \%$ representing 32 patients with \\
\hline & & $8 \%$ discontinuing treatment \\
\hline $\begin{array}{l}\text { Treatment with Hydroxychloroquine } \\
\text { alone }\end{array}$ & $19.9 \%(n=54)$ & $\begin{array}{l}\text { Cardiac arrest signifying } 13.3 \% \text { and anomalous ECG } \\
\text { outcomes representing } 27.3 \%\end{array}$ \\
\hline $\begin{array}{l}\text { Treatment with Hydroxychloroquine } \\
\text { and Azithromycin combined }\end{array}$ & $25 \cdot 7 \%(\mathrm{n}=189)$ & $\begin{array}{l}\text { Cardiac arrest among } 15.5 \% \text { of the patients and unusual } \\
\text { ECG results among } 27.1 \% \text { of the patients. }\end{array}$ \\
\hline Treatment with Azithromycin alone & $10 \%(n=21)$ & $\begin{array}{l}\text { Cardiac arrest among } 6.2 \% \text { of the populace and } \\
\text { uncommon ECG outcomes in } 16.1 \% \text { of the patients. }\end{array}$ \\
\hline Treatment with Arbidol chloride & $15.67 \%$ & - \\
\hline
\end{tabular}

\section{Future Perspective}

Many of the drugs described in this study have been repurposed to manage Covid-19. Regardless, more studies are required whereby there is the utilisation of bioinformatics tools to recognise probable drug targets via combined approaches. A number of product design are being reviewed to establish a cure for Covid-19. The WHO initiated solidarity trials that are focused on evaluating the efficiency of various drug combinations among patients and across the world to allow detailed information about the effectiveness of drugs obtained through relatively huge samples to bolster outcomes. The results from various studies failed to utilise large samples. As such necessary efforts should be tasked to establish vaccines as well as genomic sequences to offer detailed information regarding the virus. The combined efforts described are imperative in the reduction of covid-19 rates.

\section{Funding}

This work has not been funded by any institution or organization.

\section{Conflict of Interest}

All authors have read and approved the final version of the manuscript. The authors have no conflicts of interest to declare.

\section{References}

[1] Mohanty SK, Satapathy A, Naidu MM, Mukhopadhyay S, Sharma S, Barton LM, Stroberg E, Duval EJ, Pradhan D, Tzankov A, Parwani AV. Severe acute respiratory syndrome coronavirus-2 (SARS-CoV2) and coronavirus disease 19 (COVID-19) - anatomic pathology perspective on current knowledge. Diagn Pathol. 2020 Aug 14;15(1):103. [PMID: 32799894]

[2] Liu YC, Kuo RL, Shih SR. COVID-19: The first documented coronavirus pandemic in history. Biomed J. 2020 Aug;43(4):328-33. [PMID: 32387617]

[3] Yang X, Yu Y, Xu J, Shu H, Xia J, Liu H, Wu Y, Zhang L, Yu Z, Fang M, Yu T, Wang Y, Pan S, Zou X, Yuan S, Shang Y. Clinical course and outcomes of critically ill patients with SARS-CoV-2 pneumonia in Wuhan, China: a single-centered, retrospective, observational study. Lancet Respir Med. 2020 May;8(5):475-81. [PMID: 32105632]

[4] World Health Organization. Coronavirus disease 2019 (COVID-19) Situation Report - 40. WHO; 2020 Feb 29. Available from:

https://www.who.int/docs/defaultsource/coronaviruse/situation-reports/20200229sitrep-40-covid-19.pdf?sfvrsn=849do665_2

[5] Hasöksüz M, Kiliç S, Saraç F. Coronaviruses and SARS-COV-2. Turk J Med Sci. 2020 Apr 21;50(SI-1): 549-56. [PMID: 32293832] 
[6] Zhou P, Yang XL, Wang XG, Hu B, Zhang L, Zhang W, Si HR, Zhu Y, Li B, Huang CL, Chen HD, Chen J, Luo Y, Guo H, Jiang RD, Liu MQ, Chen Y, Shen XR, Wang X, Zheng XS, Zhao K, Chen QJ, Deng F, Liu LL, Yan B, Zhan FX, Wang YY, Xiao GF, Shi ZL. A pneumonia outbreak associated with a new coronavirus of probable bat origin. Nature. 2020 Mar;579(7798):27073. [PMID: 32015507]

[7] Yan R, Zhang Y, Li Y, Xia L, Guo Y, Zhou Q. Structural basis for the recognition of SARS-CoV-2 by full-length human ACE2. Science. 2020 Mar 27;367(6485):1444-48. [PMID: 32132184]

[8] Siegel D, Hui HC, Doerffler E, Clarke MO, Chun K, Zhang L, Neville S, Carra E, Lew W, Ross B, Wang Q, Wolfe L, Jordan R, Soloveva V, Knox J, Perry J, Perron M, Stray KM, Barauskas O, Feng JY, Xu Y, Lee G, Rheingold AL, Ray AS, Bannister R, Strickley R, Swaminathan S, Lee WA, Bavari S, Cihlar T, Lo MK, Warren TK, Mackman RL. Discovery and Synthesis of a Phosphoramidate Prodrug of a Pyrrolo[2,1-f][triazin4-amino] Adenine C-Nucleoside (GS-5734) for the Treatment of Ebola and Emerging Viruses. J Med Chem. 2017 Mar 9;6o(5):1648-61. [PMID: 28124907]

[9] Jordan PC, Liu C, Raynaud P, Lo MK, Spiropoulou $\mathrm{CF}$, Symons JA, Beigelman L, Deval J. Initiation, extension, and termination of RNA synthesis by a paramyxovirus polymerase. PLoS Pathog. 2018 Feb 9;14(2):e10o6889. [PMID: 29425244]

[10] Eastman RT, Roth JS, Brimacombe KR, Simeonov A, Shen M, Patnaik S, Hall MD. Remdesivir: A Review of Its Discovery and Development Leading to Emergency Use Authorization for Treatment of COVID-19. ACS Cent Sci. 2020 May 27;6(5):672-83. [PMID: 32483554]

[11] Warren TK, Jordan R, Lo MK, Ray AS, Mackman RL, Soloveva V, Siegel D, Perron M, Bannister R, Hui HC, Larson N, Strickley R, Wells J, Stuthman KS, Van Tongeren SA, Garza NL, Donnelly G, Shurtleff AC, Retterer CJ, Gharaibeh D, Zamani R, Kenny T, Eaton BP, Grimes E, Welch LS, Gomba L, Wilhelmsen CL, Nichols DK, Nuss JE, Nagle ER, Kugelman JR, Palacios G, Doerffler E, Neville S, Carra E, Clarke MO, Zhang L, Lew W, Ross B, Wang Q, Chun K, Wolfe L, Babusis D, Park Y, Stray KM, Trancheva I, Feng JY, Barauskas O, Xu Y, Wong P, Braun MR, Flint M, McMullan LK, Chen SS, Fearns R, Swaminathan S, Mayers DL, Spiropoulou CF, Lee WA, Nichol ST, Cihlar T, Bavari S. Therapeutic efficacy of the small molecule GS-5734 against Ebola virus in rhesus monkeys. Nature. 2016 Mar 17;531(7594):381-85. [PMID: 26934220]

[12] Lo MK, Feldmann F, Gary JM, Jordan R, Bannister R, Cronin J, Patel NR, Klena JD, Nichol ST, Cihlar T, Zaki SR, Feldmann H, Spiropoulou CF, de Wit E. Remdesivir (GS-5734) protects African green monkeys from Nipah virus challenge. Sci Transl Med. 2019 May 29;11(494):eaau9242. [PMID: 3114268o]

[13] Lo MK, Jordan R, Arvey A, Sudhamsu J, Shrivastava-Ranjan P, Hotard AL, Flint M, McMullan LK, Siegel D, Clarke MO, Mackman RL, Hui HC, Perron M, Ray AS, Cihlar T, Nichol ST, Spiropoulou CF. GS5734 and its parent nucleoside analog inhibit Filo-, Pneumo-, and Paramyxoviruses. Sci Rep. 2017 Mar 6;7:43395. [PMID: 28262699]

[14] Sheahan TP, Sims AC, Leist SR, Schäfer A, Won J, Brown AJ, Montgomery SA, Hogg A, Babusis D, Clarke MO, Spahn JE, Bauer L, Sellers S, Porter D, Feng JY, Cihlar T, Jordan R, Denison MR, Baric RS. Comparative therapeutic efficacy of remdesivir and combination lopinavir, ritonavir, and interferon beta against MERSCoV. Nat Commun. 2020 Jan 10;11(1):222. [PMID: 31924756]

[15] Brown AJ, Won JJ, Graham RL, Dinnon KH 3rd, Sims AC, Feng JY, Cihlar T, Denison MR, Baric RS, Sheahan TP. Broad spectrum antiviral remdesivir inhibits human endemic and zoonotic deltacoronaviruses with a highly divergent RNA dependent RNA polymerase. Antiviral Res. 2019 Sep;169:104541. [PMID: 31233808]

[16] Shereen MA, Khan S, Kazmi A, Bashir N, Siddique R. COVID-19 infection: Origin, transmission, and characteristics of human coronaviruses. J Adv Res. 2020 Mar 16;24:91-8. [PMID: 32257431]

[17] Wang Y, Zhang D, Du G, Du R, Zhao J, Jin Y, Fu S, Gao L, Cheng Z, Lu Q, Hu Y, Luo G, Wang K, Lu Y, Li H, Wang S, Ruan S, Yang C, Mei C, Wang Y, Ding D, Wu F, Tang X, Ye X, Ye Y, Liu B, Yang J, Yin W, Wang A, Fan G, Zhou F, Liu Z, Gu X, Xu J, Shang L, Zhang Y, Cao L, Guo T, Wan Y, Qin H, Jiang Y, Jaki T, Hayden FG, Horby PW, Cao B, Wang C. Remdesivir in adults with severe COVID-19: a randomised, double-blind, placebo-controlled, multicentre trial. Lancet. 2020 May 16;395(10236):1569-1578. [PMID: 32423584]

[18] Ferner RE, Aronson JK. Chloroquine and Hydroxychloroquine in covid-19. BMJ. 2020 Apr 
8;369:m1432. [PMID: 32269046]

[19] Sinha N, Balayla G. Hydroxychloroquine and COVID-19. Postgrad Med J. 2020 Sep;96(1139):550-55. [PMID: 32295814]

[20] Yao X, Ye F, Zhang M, Cui C, Huang B, Niu P, Liu X, Zhao L, Dong E, Song C, Zhan S, Lu R, Li H, Tan W, Liu D. In Vitro Antiviral Activity and Projection of Optimized Dosing Design of Hydroxychloroquine for the Treatment of Severe Acute Respiratory Syndrome Coronavirus 2 (SARS-CoV-2). Clin Infect Dis. $2020 \mathrm{Jul}$ 28;71(15):732-39. [PMID: 32150618]

[21] Gautret P, Lagier JC, Parola P, Hoang VT, Meddeb L, Mailhe M, Doudier B, Courjon J, Giordanengo V, Vieira VE, Tissot Dupont H, Honoré S, Colson P, Chabrière E, La Scola B, Rolain JM, Brouqui P, Raoult D. Hydroxychloroquine and azithromycin as a treatment of COVID-19: results of an open-label nonrandomized clinical trial. Int J Antimicrob Agents. 2020 Jul;56(1):105949. [PMID: 32205204]

[22] Grayson ML, Cosgrove S, Crowe SM, McCarthy JS, Hope W, Mills J et al. Principles of antimicrobial use. In Kucers the Use of Antibiotics: A Clinical Review of Antibacterial, Antifungal, Antiparasitic, and Antiviral Drugs, Seventh Edition. CRC Press. 2017. p. 3-8.

[23] Nagot N, Kankasa C, Tumwine JK, Meda N, Hofmeyr GJ, Vallo R, Mwiya M, Kwagala M, Traore H, Sunday A, Singata M, Siuluta C, Some E, Rutagwera D, Neboua D, Ndeezi G, Jackson D, Maréchal V, Neveu D, Engebretsen IMS, Lombard C, Blanche S, Sommerfelt H, Rekacewicz C, Tylleskär T, Van de Perre P; ANRS 12174 Trial Group. Extended pre-exposure prophylaxis with lopinavir-ritonavir versus lamivudine to prevent HIV-1 transmission through breastfeeding up to 50 weeks in infants in Africa (ANRS 12174): a randomised controlled trial. Lancet. 2016 Feb 6;387(10018):566-73. [PMID: 26603917]

[24] Hakim JG, Thompson J, Kityo C, Hoppe A, Kambugu A, van Oosterhout JJ, Lugemwa A, Siika A, Mwebaze R, Mweemba A, Abongomera G, Thomason MJ, Easterbrook P, Mugyenyi P, Walker AS, Paton NI; Europe Africa Research Network for Evaluation of Second-line Therapy (EARNEST) Trial Team. Lopinavir plus nucleoside reverse-transcriptase inhibitors, lopinavir plus raltegravir, or lopinavir monotherapy for second-line treatment of HIV (EARNEST): 144-week follow-up results from a randomised controlled trial. Lancet Infect Dis. 2018
Jan;18(1):47-57. [PMID: 29108797]

[25] Cao B, Wang Y, Wen D, Liu W, Wang J, Fan G, Ruan L, Song B, Cai Y, Wei M, Li X, Xia J, Chen N, Xiang J, Yu T, Bai T, Xie X, Zhang L, Li C, Yuan Y, Chen H, Li H, Huang H, Tu S, Gong F, Liu Y, Wei Y, Dong C, Zhou F, Gu X, Xu J, Liu Z, Zhang Y, Li H, Shang L, Wang K, Li K, Zhou X, Dong X, Qu Z, Lu S, Hu X, Ruan S, Luo S, Wu J, Peng L, Cheng F, Pan L, Zou J, Jia C, Wang J, Liu X, Wang S, Wu X, Ge Q, He J, Zhan H, Qiu F, Guo L, Huang C, Jaki T, Hayden FG, Horby PW, Zhang D, Wang C. A Trial of Lopinavir-Ritonavir in Adults Hospitalized with Severe Covid-19. N Engl J Med. 2020 May 7;382(19):1787-99. [PMID: 32187464] [26] Zhu Z, Lu Z, Xu T, Chen C, Yang G, Zha T, Lu J, Xue Y. Arbidol monotherapy is superior to lopinavir/ritonavir in treating COVID-19. J Infect. 2020 Jul;81(1):e21-e23. [PMID: 32283143]

[27] Li Y, Xie Z, Lin W, Cai W, Wen C, Guan Y, Mo X, Wang J, Wang Y, Peng P, Chen X, Hong W, Xiao G, Liu J, Zhang L, Hu F, Li F, Zhang F, Deng X, Li L. Efficacy and Safety of Lopinavir/Ritonavir or Arbidol in Adult Patients with Mild/Moderate COVID-19: An Exploratory Randomized Controlled Trial. Med (N Y). 2020 May 19. [PMID: 32838353]

[28] Leneva IA, Falynskova IN, Makhmudova NR, Poromov AA, Yatsyshina SB, Maleev VV. Umifenovir susceptibility monitoring and characterization of influenza viruses isolated during ARBITR clinical study. J Med Virol. 2019 Apr;91(4):588-97. [PMID: 30431664]

[29] Pshenichnaya N, Bulgakova V, Selkova E, Maleyev V, Lvov N, Leneva I, Grekova A, Shestakova I. Umifenovir in treatment of influenza and acute respiratory viral infections in outpatient care. International Journal of Infectious Diseases. 2019 Feb 1;79:103.

[30] Haviernik J, Štefánik M, Fojtíková M, Kali S, Tordo N, Rudolf I, Hubálek Z, Eyer L, Ruzek D. Arbidol (Umifenovir): A Broad-Spectrum Antiviral Drug That Inhibits Medically Important Arthropod- Borne Flaviviruses. Viruses. 2018 Apr 10;10(4):184. [PMID: 29642580]

[31] Hulseberg CE, Fénéant L, Szymańska-de Wijs KM, Kessler NP, Nelson EA, Shoemaker CJ, Schmaljohn CS, Polyak SJ, White JM. Arbidol and Other LowMolecular-Weight Drugs That Inhibit Lassa and Ebola Viruses. J Virol. 2019 Apr 3;93(8):e02185-18. 
[PMID: 30700611]

[32] Pécheur EI, Borisevich V, Halfmann P, Morrey JD, Smee DF, Prichard M, Mire CE, Kawaoka Y, Geisbert TW, Polyak SJ. The Synthetic Antiviral Drug Arbidol Inhibits Globally Prevalent Pathogenic Viruses. J Virol. 2016 Jan 6;90(6):3086-92. [PMID: 26739045]

[33] Lian N, Xie H, Lin S, Huang J, Zhao J, Lin Q. Umifenovir treatment is not associated with improved outcomes in patients with coronavirus disease 2019: a retrospective study. Clin Microbiol Infect. 2020 Jul;26(7):917-21. [PMID: 32344167]

[34] Cai Q, Yang M, Liu D, Chen J, Shu D, Xia J, Liao X, Gu Y, Cai Q, Yang Y, Shen C, Li X, Peng L, Huang D, Zhang J, Zhang S, Wang F, Liu J, Chen L, Chen S, Wang Z, Zhang Z, Cao R, Zhong W, Liu Y, Liu L. Experimental
Treatment with Favipiravir for COVID-19: An OpenLabel Control Study. Engineering (Beijing). 2020 Mar 18. [PMID: 32346491]

[35] Furuta Y, Komeno T, Nakamura T. Favipiravir (T705), a broad spectrum inhibitor of viral RNA polymerase. Proc Jpn Acad Ser B Phys Biol Sci. 2017;93(7):449-63. [PMID: 28769016]

[36] Goldhill DH, Te Velthuis AJW, Fletcher RA, Langat P, Zambon M, Lackenby A, Barclay WS. The mechanism of resistance to favipiravir in influenza. Proc Natl Acad Sci U S A. 2018 Nov 6;115(45):11613-18. [PMID: 30352857]

[37] Chen C, Huang J, Cheng Z, Wu J, Chen S, Zhang Y, Chen B, Lu M, Luo Y, Zhang J, Yin P. Favipiravir versus arbidol for COVID-19: a randomized clinical trial. MedRxiv. 2020 Jan 1.

Keywords: Lopinavir, COVID-19, Ritonavir, SARS-CoV-2, Chloroquine, Remdesivir, Favipiravir, Arbidol, 